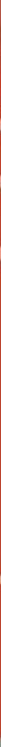

Routledge Advances in Sociology

\title{
SHARED HOUSING, SHARED LIVES
}

\section{EVERYDAY EXPERIENCES ACROSS THE LIFECOURSE}

Sue Heath, Katherine Davies, Gemma Edwards and Rachael M. Scicluna

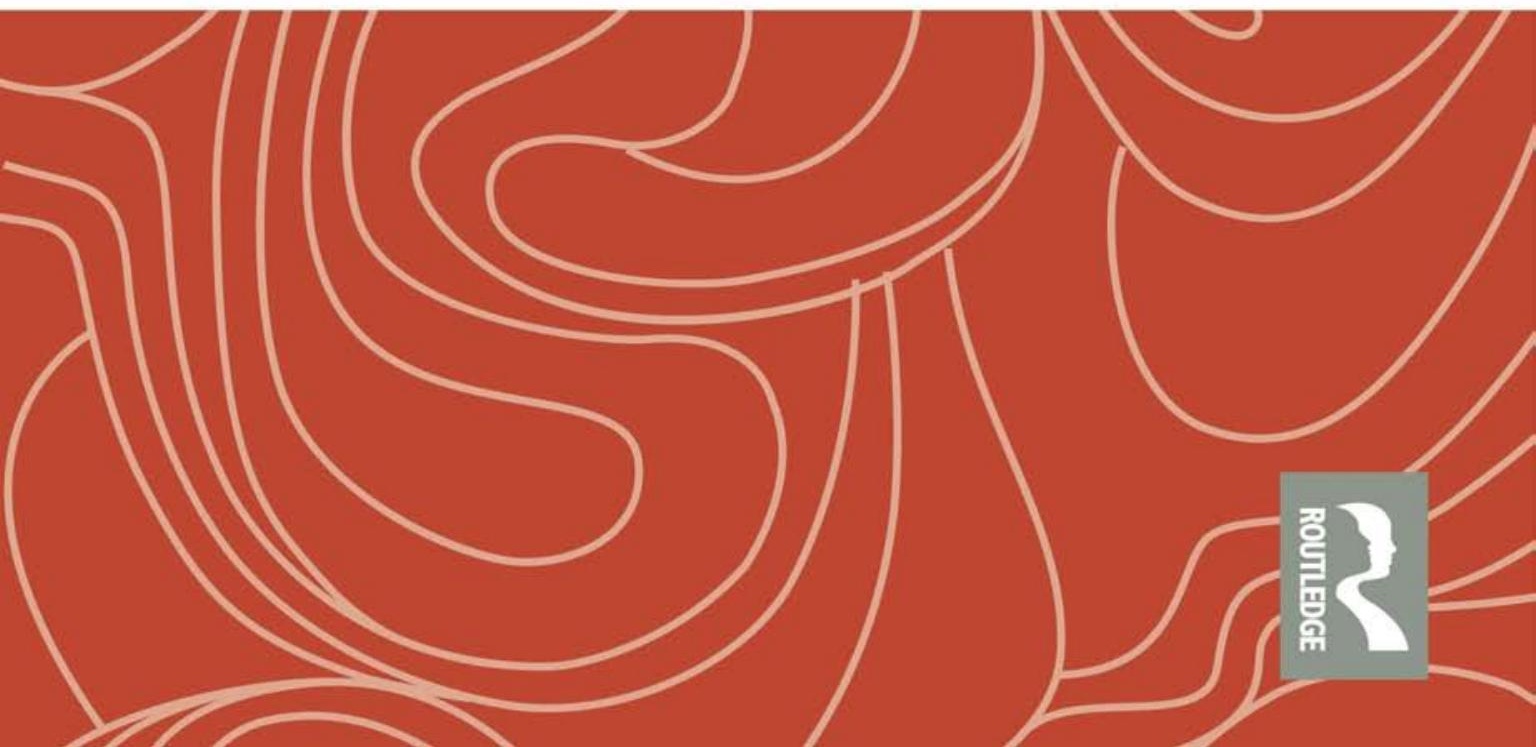


Shared Housing, Shared Lives provides important theoretical and ethnographic accounts of shared living arrangements, ranging from the familiar spare-room lodger, and multi-person house-share, to strong ideological commitment to values of collective living. In a climate of austerity, many more people in the UK find themselves sharing their homes and habits with housemates, and the authors of this book invite you to step inside the material spaces and social, sensory proximities of day-to-day sharing. At last, an incisive and nuanced analysis of shared housing.

Dr Helen Jarvis, Reader in Social Geography, Newcastle University, UK

While standard nuclear family households loom large in imaginings of contemporary domestic relations, not least among planners and policy makers, in recent years, sharing a home with strangers has become a more common experience. Across developed societies, supportive links between life-course transitions and ascent up a housing ladder have become increasingly fragile and movement, markedly non-linear, with this pattern exacerbated by recent economic crises. This book represents the most advanced and thorough analysis of the current conditions of sharing households. It builds on a deep contextual knowledge of the rise and conditions of contemporary sharers as well as important empirical insights from English cases.

Professor Richard Ronald, Professor of Housing, Society and Space, Centre for Urban Studies, University of Amsterdam, The Netherlands 



\section{Shared Housing, Shared Lives}

With a growing population, rising housing costs and housing providers struggling to meet demand for affordable accommodation, more and more people in the UK find themselves sharing their living spaces with people from outside of their families at some point in their lives.

Focusing on sharers in a wide variety of contexts and at all stages of the lifecourse, Shared Housing, Shared Lives demonstrates how personal relationships are the key to whether shared living arrangements falter or flourish. Indeed, this book demonstrates how issues such as finances, domestic space and daily routines are all factors which can impact upon personal relationships and wider understandings of the home and privacy.

By directing attention towards people and relationships rather than bricks and mortar, Shared Housing, Shared Lives is essential reading for students and researchers in fields such as sociology, housing studies, social policy, cultural anthropology and demography, as well as for practitioners working in these areas

Sue Heath is Professor of Sociology and Co-Director of the Morgan Centre for Research into Everyday Lives, University of Manchester, UK.

Katherine Davies is Lecturer in Sociology at The University of Sheffield, UK.

Gemma Edwards is Senior Lecturer in Sociology at the University of Manchester, UK.

Rachael M. Scicluna is a Lecturer in the School of Anthropology and Conservation at the University of Kent, UK. 


\section{Routledge Advances in Sociology}

For a full list of titles in this series, please visit www.routledge.com/series/SE0511

225 New Immigration Destinations

Migrating to Rural and

Peripheral Areas

Ruth McAreavey

226 Open Borders, Unlocked Cultures

Romanian Roma Migrants in

Western Europe

Edited by Yaron Matras and

Daniele Viktor Leggio

227 Digital Music Distribution

The Sociology of Online Music

Streams

Hendrik Storstein Spilker

228 Liberalism 2.0 and the Rise of China

Global Crisis and Innovation

David Tyfield

229 The Quantified Self in Precarity

Work, Technology and

What Counts

Phoebe Moore

230 Theorizing Digital Divides

Massimo Ragnedda and

Glenn W. Muschert
231 Child Figures, Literature, and Science

Fragile Subjects

Edited by Jutta Ahlbeck,

Päivi Lappalainen, Kati Launis

and Kirsi Tuohela

232 Mass Shootings in

Comparative Perspective

Communities and Shared

Experiences in the Aftermath

Johanna Nurmi

233 Mega-Events as Economies of the Imagination

Creating Atmospheres for

Rio 2016 and Tokyo 2020

Rodanthi Tzanelli

\section{Senses In Cities}

Experiences Of Urban Settings

Edited by Kelvin E.Y. Low and

Devorah Kalekin-Fishman

\section{Shared Housing, Shared Lives}

Everyday Experiences Across the Lifecourse

Sue Heath, Katherine Davies,

Gemma Edwards and

Rachael M. Scicluna 


\section{Shared Housing, Shared Lives \\ Everyday Experiences Across the Lifecourse}

Sue Heath, Katherine Davies,

Gemma Edwards and

Rachael M. Scicluna

Routledge

需 Taylor \& Francis Group

LONDON AND NEW YORK 
First published 2018

by Routledge

2 Park Square, Milton Park, Abingdon, Oxon OX14 4RN

and by Routledge

711 Third Avenue, New York, NY 10017

Routledge is an imprint of the Taylor \& Francis Group, an informa business

(C) 2018 Sue Heath, Katherine Davies, Gemma Edwards and

Rachael M. Scicluna

The right of Sue Heath, Katherine Davies, Gemma Edwards and Rachael M. Scicluna to be identified as authors of this work has been asserted by them in accordance with sections 77 and 78 of the Copyright, Designs and Patents Act 1988.

All rights reserved. No part of this book may be reprinted or reproduced or utilised in any form or by any electronic, mechanical, or other means, now known or hereafter invented, including photocopying and recording, or in any information storage or retrieval system, without permission in writing from the publishers.

Trademark notice: Product or corporate names may be trademarks or registered trademarks, and are used only for identification and explanation without intent to infringe.

British Library Cataloguing in Publication Data

A catalogue record for this book is available from the British Library

Library of Congress Cataloging in Publication Data

A catalog record for this book has been requested

ISBN: 978-1-138-67353-3 (hbk)

ISBN: 978-1-315-56188-2 (ebk)

Typeset in Times New Roman

by Wearset Ltd, Boldon, Tyne and Wear 


\section{Contents}

Acknowledgements viii

1 Shared living in context 1

2 Shared living and domestic intimacy: the challenges of sharing

3 Pathways into sharing: experience and ideology 38

4 The economic and material organisation of shared living 61

5 The spatial organisation of shared living 81

6 Time matters in shared living $\quad 98$

7 Shared housing, shared lives? 122

Appendix: pen portraits of participants in the Under the Same Roof project

Index 


\section{Acknowledgements}

This book is based upon research funded by the Economic and Social Research Council: Under the Same Roof: The Everyday Relational Practices of Contemporary Communal Living (award reference ES/K006177/1). We are grateful to the ESRC for funding this research and are of course hugely indebted to all of the sharers who agreed to tell us about their experiences with such openness and generosity.

Throughout the project we received excellent advice and support from our advisory group members. Many thanks to the following people who were involved in the group at various points in the life of the project: Ella Wesolowicz and Rebecca Derham of Crisis, Matt Hutchinson of SpareRoom, Dawn Astin of St Vincent's Housing Association and Accent Housing, Julie Craik and Mike Wright of Salford City Council, Sarah Lowe of Bolton at Home, Maria Brenton and Jo Gooding of the UK Cohousing Network, Lucy Woodbine of New Economy, Cathy Ayrton of MHA, Safia Griffin, and Jennifer Mason of the Morgan Centre.

We would also like to thank Jen Kettle for her excellent assistance, Kirsty Morrin and Laura Fenton for their invaluable help at various points in the project's life, and Emily Briggs and Elena Chiu at Routledge for their part in bringing the book to fruition. Thank you, too, to all our wonderful colleagues in the Morgan Centre for Research into Everyday Lives who took an interest in our project right from its inception. We extend our warmest thanks to Hazel Burke and Vicky Higham who were such an important part of the team.

The quotation which appears on page 1 from Sarah Waters' 2014 novel The Paying Guests appears by kind permission of the author and the publishers, Little, Brown Book Group. 


\section{Shared living in context}

\section{Introduction}

In the opening chapter of her acclaimed 2014 novel The Paying Guests, Sarah Waters vividly brings to life the sense of shame and embarrassment experienced by respectable middle class English families who, in order to make ends meet after the First World War, were obliged to take in lodgers. Her protagonist, Frances Wray, is awaiting the arrival of the Barbers, a brash young couple of a lower social status, and is anxious to get the moment over with as quickly and painlessly as possible. She hands over a set of keys to Mrs Barber, who in return hands over two weeks' rent in a brown envelope, which Frances tucks away in a deliberately casual manner whilst trying to downplay the significance of this exchange. Later, she hears the Barbers moving around, coughing, laughing, with each very ordinary sound seeming like an extraordinary intrusion. The next morning, the splashing of Mrs Barber in the bath tub is audible through the thin walls, and the reality of Frances' new domestic arrangements hits home to her:

This was what it really meant to have lodgers: this odd, unintimate proximity, this rather peeled back moment, where the only thing between herself and a naked Mrs Barber was a few feet of kitchen and a thin scullery door.

(Waters, 2014, p. 28)

This account beautifully conjures up the apprehension and sense of unease still felt by many at the prospect of having to share their living space with people to whom they are unrelated. This is a theme which has long featured in literary fiction (see Mulholland, 2016; Cuming, 2016), with many well-known nineteenth and twentieth century writers featuring boarding houses and lodgings in their work. H.G. Wells, for example, wrote compellingly of everyday boarding house life in novels such as Kipps and Ann Veronica, as did later writers such as George Orwell (Keep the Aspidistra Flying) and Lynne Reid Banks (The L-Shaped Room). More recent portrayals of shared living arrangements in popular culture have continued to stress the challenges arising from close proximity to relative strangers. In particular, the comic potential of life in shared housing is a staple theme of sit-coms and soap operas, whether in classic shows 


\section{Shared living in context}

such as Friends, This Life, Rising Damp and The Young Ones, or in more recent examples such as The Big Bang Theory, Crashing and New Girl. Although some shows in this genre represent shared living as an aspirational and desirable lifestyle choice of the young and glamorous, most derive their comedy from the mishaps and misunderstandings that can arise when living with non-kin, whilst advice books on house shares and lodging arrangements invariably include chapters on potential problems and flashpoints (Hunt and Hutchinson, 2009; Shepperson, 2010). Cumulatively, these representations suggest that the phenomenon of shared living continues to be underpinned by widely shared assumptions about its transitory nature, its volatility, its likely success or failure, and even at times its slight oddness in comparison with living arrangements which are both more familiar and more familial.

Nonetheless, with a growing population, rising housing costs and housing providers struggling to meet demand for affordable accommodation, more and more people in the United Kingdom (UK) are sharing their living spaces with people from outside of their families at some point in their lives, however fleetingly. People's reasons for living in shared housing vary hugely, from unqualified financial necessity at one extreme through to a desire to embrace alternative and more communal living arrangements at the other. As popular representations make very clear, though, all shared living arrangements are united by the centrality of everyday relationships to their success or failure. If relationships are good, sharing can work really well; if they are bad, shared housing can become a nightmare. This applies as much to those who deliberately choose to live communally as it does to those sharing largely for reasons of constraint. Yet the quality of relationships in shared contexts is rarely a product of chance alone, and can be profoundly affected by the nature and quality of the practices of sharing which develop in any given household.

In this book we go through the front doors of shared housing to meet sharers of all ages and all motivations to explore the day-to-day practicalities of their living arrangements. Drawing on data from the Under the Same Roof project - a qualitative research project based at the Universities of Manchester and Sheffield involving residents of shared rentals, shared housing co-operatives, private lodgings and cohousing schemes - we focus in particular on how people's motivations for living together and the ways in which they organise the sharing of finances, domestic space and daily routines can affect the quality of their personal relationships. Our focus, then, is primarily on people and relationships rather than bricks and mortar as we seek to demonstrate how the mundane, everyday practices of shared living provide the key to whether they falter or flourish. Nonetheless, as we shall demonstrate, bricks and mortar are not irrelevant to these practices, as the physical architecture of shared housing can have a profound impact on the nature of the relationships and daily practices that emerge.

In this introductory chapter, we place contemporary shared living arrangements in the UK in their broader context, considering their incidence and some of the factors that have led to them becoming more common at particular 
moments in people's lives. These factors include the state of the UK housing market in the years since the 2008 global financial crisis and the policy responses of successive UK governments. We then move on to provide an introduction to the Under the Same Roof project and outline its aims and objectives and the key features of its research design. Finally, we outline the structure of the book and summarise our overall argument.

\section{Twenty-first century shared living}

Despite our focus on shared households, it is important to remind ourselves that most people, for most of the time, do not live with non-kin. In 2015, 57 per cent of all UK households consisted of a couple with or without children, and a further 29 per cent consisted of one person households (ONS, 2015a). These figures have remained relatively consistent since the mid-1990s. As for the proportion of households consisting of sharers, precise figures are difficult to come by, as government statisticians place shared living arrangements involving nonkin into an umbrella 'other household' category. This category, defined as 'a multi person household that is neither a couple household nor a lone parent household' (DCLG, 2013: 23), includes a diversity of household forms that do not conform to conventional couple or family-based living arrangements. It includes not only unrelated sharers, but also co-residents who are related to each other outside of a parent-child or couple relationship, such as siblings and cousins, as well as adult children living with just one parent. The proportion of households in the 'other household' category rose from 6.6 per cent of all households in England and Wales in 2001 to 7.9 per cent in 2011 (ONS, 2014, Table 4), and is predicted to rise further by 2021 (DCLG, 2013). This increase may appear modest in absolute terms, yet represents the largest percentage change compared with other household types over the same period (ibid.).

Two further household type categories used in government surveys include potential sharers: 'couple with other adults' and 'lone parent, with or without other adults'. Eleven per cent of households were in the former category in 2011, and 7.7 per cent in the latter, with both categories also predicted to rise by 2021 (DCLG, 2013). Any shared household involving at least one couple or a lone parent and dependent child(ren) in addition to any number of unrelated others, whether lodgers, joint tenants, or in some other form of sharing relationship, would come under these two categories. But as with the 'other household' category, these 'other adults' living alongside the couple or lone parent also include relatives such as grandparents, aunts and uncles, siblings, or nieces and nephews. Tellingly, the presence of the couple/lone parent and any children also takes precedence in the allocation of household type regardless of how many other (unrelated) adults reside within the household. For example, a shared housing co-operative of eight residents, two of whom formed a couple, would be classified as 'couple with other adults'.

Whilst definitive figures are hard to find, those working directly in the shared housing sector are strongly of the view that shared living arrangements have 


\section{Shared living in context}

become much more common in recent years. One of the leading UK shared housing websites, SpareRoom, has seen the number of adverts placed on its site rise from 140,000 in 2010 to 700,000 in 2016, a five-fold increase, alongside a doubling of the proportion of those placing adverts in the 45-plus age bracket, rising from 3.8 per cent of all advertisers in 2007 to 8.6 per cent in 2016 (Hutchinson, 2017). Moreover, the insurance firm LV has suggested that the proportion of people in Great Britain letting a room almost doubled between 2009 and 2014 (Parkinson, 2015).

There is no doubt that these shifts are closely linked to dramatic changes in the housing market in recent years, especially in the wake of the 2008 financial crisis, and which have left many people struggling to meet their housing costs (Bone and O'Reilly, 2010; Stephens and Stephenson, 2016). Factors such as the collapse of the sub-prime mortgage market, year-on-year house price increases, reduced mortgage availability and the breaking of the link between average house prices and average earnings have affected housing affordability for people of all ages (ONS, 2015b; Saunders, 2016). Nonetheless, they have had a disproportionate impact on younger people, to the point that more 25 to 34 year olds now live in rented accommodation than in houses of their own (DCLG, 2016) - hence the label 'Generation Rent' (McKee, 2012; Willetts, 2010; Howker and Malik, 2010). So whilst home ownership remains a common aspiration across all age groups, and continues to gain ideological support through various forms of government subsidy and Help to Buy schemes, it is increasingly beyond the reach of many, especially younger people (Hoolachan et al., 2017; Walker and Jeraj, 2016; Dorling, 2014) as well as many members of socio-economic groups who have long been excluded from home ownership (Bone and O'Reilly, 2010). The costs of renting a whole house or even a small flat are equally prohibitive to many, especially to those who are reliant on a single income to cover their housing costs. Consequently, as the housing crisis has tightened its grip on the UK, living in shared tenancies in the private rented sector (PRS) has become a common feature of the housing pathways of many people, including but by no means confined to young adults seeking independence from the parental home. At the same time, renting out spare bedrooms to lodgers is a common response by those who have managed to get onto the housing ladder yet are struggling to otherwise meet their mortgage payments. Notably, in 2011 approximately 15 per cent of men and 9 per cent of women in the 25 to 34 year old age category were living in 'other, multi-person households' (ONS, 2012), many of whom were likely to have been situated in shared tenancies and private lodging arrangements.

Earlier research conducted by one of us in the late 1990s (Heath and Cleaver, 2003) suggested that shared tenancies were commonly viewed by young people as time-limited living arrangements prior to living on one's own or with a partner, and all within a relatively short-term time frame, yet today's sharers often feel that they have no such guarantees (Heath, 2017). The housing pathways of Generation Rent are instead frequently characterised by precarious movement through successive house shares in the PRS (Rugg and Quilgars, 
2015). These moves are often interspersed by returns to the parental home (Sage et al., 2013; Stone et al., 2014; Lewis et al., 2016; Roberts et al., 2016) and by lowered expectations of gaining security of tenure through early access either to owner occupation or to the residualised social housing sector, unless in the case of owner occupation they are able to call on the resources of 'the Bank of Mum and Dad' (Hoolachan et al., 2016; Heath and Calvert, 2013; Druta and Ronald, 2017). The PRS, not least in the form of shared tenancies, is then playing an ever greater role in younger people's housing pathways, despite its many inadequacies as a tenure (Rugg and Rhodes, 2008; Walker and Jeraj, 2016).

In the broader European context, this level of reliance on shared housing amongst young adults has, at least until recently, been largely specific to the UK (Arundel and Ronald, 2016). Although it is not uncommon for young people in some but by no means all European countries to live in shared housing as students (Steinführer and Haase, 2009), graduates and non-students in northern Europe and Scandinavia wishing to live independently from the parental home have largely been able to access affordable accommodation on their own rather than having to share (Albertini and Kohli, 2013). In many southern and eastern European countries, in contrast, it is much more common to remain within the parental home until a young person is able to afford a home of their own: young people from these regions of Europe are amongst the last to leave the parental home and display an ongoing dependency on parents even after having left (Kemeny, 2005). The material burden of independent home ownership in these countries is also more likely to be eased by family members helping with the acquisition of a site on which to build a house (Mandic, 2008 and 2010), donations of cash towards the payment of home loans or required deposits, and the allocation of family property, including through inheritance from both the parental and grandparental generation (Emmanuel, 2014; Allen et al., 2004; Flaquer, 2000). Hence the family still acts as a backbone in helping out the younger generation in purchasing a home, reflecting differing intergenerational transfer regimes across different parts of Europe (Albertini and Kohli, 2013).

The 'age of austerity' ushered in by the 2008 financial crisis has also been accompanied in the UK by a series of reforms which have impacted upon the actual and potential incidence of shared living. In January 2012 the Coalition Government extended the Shared Accommodation Rate (SAR) to single under35 year old Housing Benefit claimants as part of its wider benefit reforms. SAR was originally introduced in 1996 as the Single Room Rent policy, restricting Housing Benefit payments for single under-25 year olds to the locally-assessed average cost of a room in a shared household. Its extension to under-35 year olds went ahead despite evidence of an existing shortfall in the availability of accommodation for under-25 year old claimants needing to share (Rugg et al., 2011; Sanders and Texeira, 2012). The extension was justified by Chancellor George Osborne on the grounds that it reflected 'the housing expectations of people of a similar age not on benefits' (Hansard, 2010, col. 958). Yet sharers dependent on Housing Benefit experience very different constraints and opportunities compared with non-claimant sharers, and accordingly have vastly different expectations and 
experiences (Clarke and Heywood, 2016; Green and McCarthy, 2015; OrtegaAlcazar and Wilkinson, 2017). Osborne's justification was challenged at the time by Green Party MP Caroline Lucas for being completely out of touch with the reality of shared living:

The Government like to present the shared room rate proposal as an extension of the idea of a group of young friends living together as their children might after university. That is a seductive argument, but only because it is so simplistic.

(Hansard, 2011, col. 297WH)

Other housing reforms introduced by the Coalition Government and continued by the Conservative Government after the 2015 election are linked to an emergent politics of under-occupancy, whereby politicians and others have rendered the possession of spare bedrooms a moral issue for certain groups (Greenstein et al., 2016). There are two main strands to these concerns. The first relates to under-occupancy in social housing and the introduction in 2013 of the Spare Room Subsidy (SRS). Colloquially known as 'the bedroom tax', SRS results in a reduction in Housing Benefit for working age social housing tenants if a household is deemed to have too many bedrooms for the specific number and configuration of people living in the house (Gibb, 2015). Claimants in possession of bedrooms deemed to be 'spare' after certain rules of acceptable occupancy are applied are then penalised: a 14 per cent reduction in Housing Benefit for one spare room and a 25 per cent reduction for more than one spare room. Architects of the policy assumed that tenants would either downsize their homes or be willing to rent out their spare room(s) rather than face a financial penalty. Yet successive evaluations have demonstrated a severe shortage of smaller properties (Gibb, 2015; DWP, 2015), an unwillingness to move away from close-knit communities even if the possibility of downsizing exists (Bogue, 2017) and little evidence of an appetite for sharing amongst affected tenants, despite efforts by social housing providers to encourage private lodging arrangements (DWP, 2015; Green and McCarthy, 2015). This highlights the undesirability of shared living arrangements for many people, even when having a lodger might ameliorate the financially crippling effects of the SRS. As one social tenant expressed it when interviewed for a government-sponsored evaluation, 'We wouldn't want a stranger in our home, no matter how much easier it'd be paying the bills' (DWP, 2015, p. 58).

The second strand of the under-occupancy debate relates to what has been termed 'the hoarding of housing' by older generations (Griffith, 2011). The Intergenerational Foundation has claimed that there are 25 million surplus bedrooms in England's housing stock and that 'the current housing crisis is not principally about Britain having enough housing but about the way it is shared between older and younger generations' (ibid., p. 2). The Foundation asserts that 16 million people live in under-occupied properties in England, which is equivalent to 37 per cent of the total English housing stock. Older 'hoarders' are thus 
exhorted either to downsize to smaller properties to make way for families, despite a chronic lack of housing choice (Park and Ziegler, 2016), or to rent out their spare rooms to lodgers, even though many of these rooms are regularly used by visiting family members, including as part of child care provision for grandchildren. Nonetheless, in some cases acquiring a lodger could make it possible for an older person to remain in their home against pressures to downsize or even to move into residential care. The organisation 'Homeshare International' has responded to these concerns by promoting mutually beneficial intergenerational sharing arrangements whereby an older person provides lodgings to a younger person for little or no rent in exchange for a set number of hours of assistance around the house. However, such schemes often prove difficult to get off the ground and so far the numbers involved in Homeshare schemes in the UK remain small (SharedLivesPlus, 2016).

In recent years there has also been a modest groundswell of interest in the UK in alternative housing provision such as cohousing, community land trusts and self-build schemes (Rowlands, 2010; Moore and McKee, 2012; Lloyd et al., 2015). Cohousing is of particular interest here, as it a hybrid form of shared living, involving individual dwellings alongside the provision of shared facilities located in a 'common house'. At a minimum, the common house will usually include shared cooking and dining facilities for regular common meals, but often alongside much more extensive facilities such as shared laundries, workshops, playrooms, lounges and guest bedrooms (McCamant and Durrett, 2011, p. 25). As most cohousing schemes in the UK are based on a model of private home ownership, most cohousers are, unsurprisingly, from relatively affluent backgrounds. Nonetheless, supporters of cohousing point to its potential to engage with at least three key challenges: environmental sustainability and low-impact living (Williams, 2005a; Mulder et al., 2006; Chatterton, 2015); financial sustainability (Sazama, 2003; LILAC Cooperative, 2011); and the creation of supportive and inclusive all-age communities (Brenton, 2011; Shin Choi, 2004; Graber and Wolfe, 2004; Wann, 2005).

For similar reasons, there has also been some wider interest in co-operative and mutual forms of housing as alternatives to mainstream models of private ownership. For example, a government-sponsored review of co-operative and mutual housing underlined the sector's potential to produce 'sustainable mutually supportive communities with less reliance on the state' which could potentially 'stimulate active citizenship and community resilience' (Bliss, 2009, pp. 6-7). The majority of existing stock in the co-operative and mutual housing sector consists of tenant management organisations and tenant-controlled (or community-based) housing associations managing large quantities of conventional housing stock on behalf of local councils and housing associations. However, the sector has long included a type of co-operative known as 'ownership housing co-operatives', which as the name suggests are based not just on mutual control and management but mutual ownership as well. These tend to operate on a very small scale, often consisting of a single shared property occupied by a group of unrelated members. This is arguably co-operative housing in 


\section{Shared living in context}

its purest form, and many existing ownership housing co-operatives have their roots in the UK squatter movement of the 1970s. Although the sharing of resources, the development of group identity, and a commonality of basic aims often emerged in these squats, the primary motivation for most squatters remained the pressing need for an affordable roof over their heads (Kearns, 1981; Harrison and Reeve, 2002), and this remains an important motivation for members of ownership housing co-operatives in the UK today.

All of the factors outlined above have created a situation whereby awareness of shared living arrangements has arguably increased in recent years, and where many people now find themselves - perhaps unexpectedly - sharing at diverse and multiple points in the lifecourse. Whilst living with non-kin for extended periods of time may be an expected rite of passage for younger sharers, older people may find themselves sharing for the first time at a point beyond which they would never have envisaged doing so, perhaps following a spell of unemployment or a relationship breakdown. Regardless of circumstances, relatively little remains known about the everyday experiences of sharers, especially older sharers whose lives are largely unexplored within sociological literature on personal life, and through this book we seek to step into that gap.

\section{Introducing the Under the Same Roof project}

This, then, is the backdrop against which we conducted the research for the Under the Same Roof project, in which we sought to explore and understand everyday practices of sharing in contemporary shared living arrangements. It is our strong contention that the capacity and appropriateness of shared living arrangements to rise to some of the challenges of current and future housing provision depends on the nature and quality of the relationships within them, which in turn are affected by the range of resources available to sharers in coping with the day-to-day realities of living with non-kin, whether financial, material, social or emotional resources. Accordingly, we set out to explore the 'critical associations' (Davies and Heaphy, 2011) which exist within different shared contexts, an idea we explore further in Chapter 2. We also wanted to explore the potential mismatch or fit between expectations of sharing and the actual practices which emerge within communal contexts. This is especially relevant to contexts where expectations may be particularly high, such as in a cohousing scheme or a cooperative, but is arguably an issue in all forms of shared housing. Ultimately, we wanted to explore the extent to which the sharing of housing implies the sharing of lives.

We defined shared living arrangements in terms of co-residence based on the full or partial sharing of domestic space by groups of people who were unrelated to each other, although not necessarily consisting only of non-kin. Accordingly, our sample included sharers living with partners and/or children alongside nonkin: for example, couples living in shared housing co-operatives, or single parent householders who had taken in lodgers. For the most part, though, the sharers included in our research did not have resident partners or children. Importantly, 
our baseline definition did not assume that shared housing necessarily extended beyond the sharing of a roof. Rather, the extent to which other aspects of daily life were in practice shared formed the focus of our empirical enquiry and, as will become clear throughout the book, we found huge variation between and within different contexts. We nonetheless use the term 'sharing' throughout this volume, mainly because this was the term used by virtually all our participants throughout the research and which was most easily understood to mean 'sharing with non-kin' when explaining our research to potential participants and stakeholders. The fact that living with kin is not commonly referred to as 'sharing' conveys the taken-for-granted nature of familial living arrangements and relationships in comparison to sharing with non-kin. Whilst we find the term 'sharing' useful for these reasons, we are aware that its positive connotations can also obscure the power relationships, tensions and inequalities experienced by many of our participants and we endeavour to bring these aspects to light in the coming chapters.

We also excluded shared living arrangements in institutional or commercial contexts, such as halls of residence, care homes, guest houses, retirement villages or religious communities, mainly because we were primarily interested in shared households which are, for the most part, self-sufficient in terms of their daily routines, rather than reliant on paid staff who are either non-resident or who do not enjoy the same status as those in receipt of the services. We chose then to focus our fieldwork on four contrasting forms of shared living in private domestic settings: shared households in the private rented sector, private lodging arrangements, shared housing co-operatives, and cohousing, all four of which have been invoked in recent debates surrounding some of the challenges of UK housing provision. Each is briefly introduced below.

Shared households in the private rented sector constitute the most common form of sharing in the UK and are largely associated with the transitional living arrangements of single young adults, as they are often the only affordable option for those wishing to live independently of their parents (Heath, 2017; Roberts, 2013). This type of sharing is particularly common amongst higher education students in the UK, and generates lively debates about the 'studentification' of local neighbourhoods, often leading to attempts by local authorities to curb its proliferation (Kenyon, 1999; Munro and Livingston, 2012). Many students continue to share as graduates, placing particular value on the flexibility of shared tenancies in the PRS and the access they often afford to a ready-made social life (Kenyon and Heath, 2001; Heath and Kenyon, 2001). This segment of the shared housing market is well served by agencies providing so-called 'professional house shares' and a plethora of websites acting as brokers between landlords and potential tenants. For reasons outlined earlier, the population of sharers in the PRS also includes many young people on low incomes and in receipt of Housing Benefit, often living in sub-standard accommodation (Green and McCarthy, 2015). There is, then, considerable polarisation in this sector in the quality of housing experienced by sharers. Moreover, whilst the sector is mainly the preserve of younger adults, there is growing evidence that individuals in midlife 
and beyond are also reliant on it for at least short periods of time, as a fall-back position for those who have lost their homes for reasons such as repossession, eviction or relationship breakdown. SpareRoom has, as noted, seen an increasing proportion of users who are searching for rooms via its website being drawn from the 45-plus age bracket, rising from 3.1 per cent of all searchers in 2006 to 8.6 per cent in 2016 (Hutchinson, 2017).

Private lodging arrangements are based on the renting of spare rooms to lodgers by a resident landlord or landlady who may be either the home owner or the tenancy holder. Lodgers may stay for all or part of the week and may be one of several lodgers. Lodging arrangements of this kind have a long history in the UK, including the boarding of apprentices in their masters' family homes during the medieval period, boarding houses for single men and women in Victorian and Edwardian England, seaside guesthouses from the 1930s onwards and student 'digs' of the 1950s and 1960s (see for example Walton, 1978; Pooley and Turnbull, 1997; Hamlett, 2010; Davidoff, 1995). Private lodging arrangements are actively encouraged by the 'Rent a Room' scheme, which allows householders to earn tax-free income by renting out furnished rooms in their homes, and has arguably provided an increasing number of householders with a means of holding onto their housing in the face of financial difficulties. In 2008, at least 260,000 people lodged in 198,000 households in England (Survey of English Housing, Table S563), rising to 227,000 households by 2012 (DCLG, 2014), with other sources suggesting the increase has been much bigger (Parkinson, 2015). It has also been suggested that the hitherto common arrangement of an older single woman renting rooms largely to single young men has been superseded by single young adults of both genders living with married couples of a similar age to them $(\mathrm{LV}, 2010)$. This has been attributed to the rise of the 'friendlord', with the majority of landlords and landladies apparently now renting to people already known to them rather than to strangers (ibid.).

The shared housing co-operatives included in our research are all examples of what are technically known as ownership housing co-operatives. In general terms, housing co-operatives are based on the democratic control and management by tenants of their homes. In the UK context, the term is often used quite loosely to apply to a range of schemes involving an element of mutuality, yet which operate on vastly different scales: as we noted above, ranging from community-based housing associations managing several thousand properties through to ownership housing co-operatives which often consist of a single shared property or a small number of adjacent shared properties. Ownership housing co-operatives are underpinned by a model of mutual ownership whereby all tenants are directors of the company owning the property; all directors are tenants; and all pay rent to the company. A shared housing co-operative run on this basis therefore provides 'rented housing without landlords, or rather the tenants are collectively their own landlord' (Radical Routes, 2015, p. 4). Ownership housing co-operatives, which are typically located in ordinary residential properties in urban areas, are the most overtly ideological form of shared living included in our study. Members share at least some commitment to co-operative 
principles, whilst many are also involved in workers' co-operatives or share various other ideological positions (ibid.). Co-op members thus expect to live with and negotiate ideological influences on a daily basis in a way that is either absent or less transparent in other shared contexts.

Cohousing is relatively new to the UK. As previously noted, it is a hybrid form of communal living, with residents retaining separate residences yet sharing many other elements of domestic life, thus balancing privacy with communality (Williams, 2005b). Cohousing has several core features: resident management (including management of the initial planning and design process); architectural designs that facilitate community; extensive shared facilities in a common house and other on-site locations; non-hierarchical structures; and the retention of separate incomes (McCamant and Durrett, 2011, p. 25). As of spring 2017 there were 19 established schemes affiliated to the UK Cohousing Network, involving a mix of ages, household type and tenure (including some schemes which are run as co-operatives), with most existing developments located in small towns or in rural locations. At least another 65 schemes are in various stages of development, including a fair number now being developed in cities (cohousing.org.uk/cohousing-uk). Some cohousing schemes are specifically targeted at older people, and the members of the first UK cohousing scheme for older people - in this case, women only moved into their new homes in late 2016.

\section{Our research methods}

Our research utilised a variety of methods. We first mapped the landscape of shared living in the UK. This involved bringing together information from directories and literature produced by organisations such as the UK Cohousing Network, Radical Routes, Co-operatives UK, the Confederation of Co-operative Housing and Diggers and Dreamers, and online searches for other forms of shared housing. We constructed a database containing details of a wide range of shared living arrangements: shared housing co-operatives and cohousing schemes, intentional communities such as religious and therapeutic communities, and other organisations which provide multiple shared living opportunities, including housing associations with shared properties in their stock, charities providing group homes to their clients, Homeshare schemes, and property guardian companies (England, 2015). We also constructed a database consisting of the website materials of many of these communities and organisations, in order to consider how they publicly represented themselves through language and visual imagery (for example, frequent references to group activities such as eating together, alongside photographs of home-grown produce).

The main phase of the research involved qualitative interviews with 64 individual sharers, mostly interviewed on their own but a few in pairs or larger groups. Interviews typically lasted between one and two hours and were held in participants' homes or local cafes and pubs. Each interview started by eliciting an unstructured account of the participant's housing pathway since first leaving home, which was particularly useful for shedding light on earlier experiences of 


\section{Shared living in context}

sharing and the place of communal living from within a lifecourse perspective. They then shifted to a semi-structured format to explore four interlinked themes: ideological and motivational aspects of shared living, its economic and material organisation, spatial aspects of sharing, and its temporal aspects, all of which are key themes that have emerged in earlier research on shared living arrangements and which we felt were worthy of further investigation. Each of these themes highlighted a distinctive aspect of sharing and together they provided contrasting but complementary 'flashes of insight' (Mason, 2011) into the overlapping dimensions of shared living. These facets of the research informed our analysis of the interview data, feeding into the coding process alongside themes arising from the data. We worked within and between these four dimensions of the research when making sense of themes and narratives arising from the data and the four themes provide the thematic structure of this book.

In addition to the interviews, some sharers also participated in one of two other methods. One group took photographs of shared and private spaces in their homes and the objects within them, and the images we received included the contents of fridges, cupboards, bathroom cabinets, bookcases, mantelpieces, notice boards, hallways, landings, gardens, garages and other external spaces. Participants were invited to discuss the significance of their chosen images as a way of exploring negotiations surrounding the use of communal versus private spaces and objects. Some of these images are reproduced in Chapters 4 and 5. We also received photographs from a small number of additional sharers who did not otherwise take part in the main phase of the research, including five people who took part in an extended photo elicitation interview and whose accounts are also drawn upon in this book to give us a total of 69 interview accounts. A second group of main phase participants was invited to keep a timeuse diary in which they recorded interactions with co-residents on two separate days, noting the activities concerned, the amount of time involved and the people with whom they interacted, including the comings and goings of non-residents. The diaries also allowed participants to reflect on their personal networks, including the place accorded to co-residents and how living communally impacted upon their broader networks. This data was subsequently analysed to generate some revealing network diagrams, and this element of the project is alluded to in Chapter 6.

Turning to our sampling strategy, most members of housing co-operatives and cohousing schemes were recruited using contact details listed in publicly accessible directories, with additional participants recruited via snowballing. Sharers living in private lodging arrangements and house shares in the PRS were more challenging to locate as there are no sampling frames as such to use. Rather we used a variety of approaches, including asking house share agencies to pass on details of our research to their tenants, using personal contacts and snowballing, and contacting people advertising for new tenants. We recruited mainly in the north of England, but also included participants in London, the Midlands, the southeast, the southwest and Scotland. Members of co-operatives and cohousing schemes were most geographically spread, given their small numbers. Most of 
the co-operatives represented in the study were located in large cities, whilst most of the cohousing schemes were in more rural locations. The house shares and lodging arrangements ranged across cities, towns and more rural locations. We aimed to interview between 15 and 20 sharers in each of the four categories, and achieved this in all but the cohousing category, where we only recruited ten people. As we had anticipated, cohousers proved to be hardest to recruit, as cohousing is currently a fashionable topic amongst housing researchers and many cohousing communities are suffering from 'research fatigue'. In addition to the four main categories of house share, our sampling strategy gave us the chance to opportunistically include a small number of sharers living in other examples of house shares based on equal tenure status: two sharers living in social housing, two who had joint mortgages with friends, and five who lived together in a large house owned by a religious organisation. We had wanted to include more sharers living in social housing as joint or individual tenants, but only a relatively small number of social housing providers currently facilitate such arrangements, although this is slowly beginning to change (see Wesolowicz and Derham, 2017). The Appendix provides brief pen portraits of each of our participants in terms of their housing pathways: the 64 main phase interview participants and the five additional sharers who took part in extended photo elicitation interviews.

As for the broader characteristics of our participants, we recruited 46 women to 23 men, despite efforts to recruit roughly equal numbers, and achieved a good spread of ages: 25 sharers aged 20 to 34,18 aged 35 to 49, another 18 aged 50 to 64, and eight aged 65-plus. Only a small number of our participants were first time sharers, whilst many - including a sizeable proportion of older sharers had shared for all or most of their adult lives, frequently having moved between different categories of shared housing at various points in their lives. A small number of sharers also owned houses elsewhere in which they did not currently live. Most of our sample members were British, predominantly but not exclusively white British, whilst we also interviewed several participants who were from various mainland European countries as well as from other parts of the globe. The majority of participants were single, although around a fifth lived with a partner in their shared house and a small number had a partner living elsewhere. Around one in ten identified as LGBT, and a similar proportion had children living with them, with a high degree of overlap between these two groups.

The majority of our participants were in paid employment, several of whom were self-employed or were members of workers' co-operatives, a small number were students (mainly postgraduates) or unemployed, and around one in ten were retired. In reporting our findings, we have tended not to give details of participants' occupations, as in many cases this information in combination with other personal characteristics would render individuals more easily identifiable, especially sharers living in cohousing schemes and shared housing co-operatives, and the protection of anonymity has remained an important guiding principle in our analysis. In terms of socio-economic status, the majority of participants were or had in the past been employed in professional, skilled or semi-skilled occupations and a 


\section{Shared living in context}

Albertini, M. and Kohli, M. (2013). 'The generational contract in the family: an analysis of transfer regimes in Europe', European Sociological Review, 29(4), pp. 828-840.

Allen, J. , Barlow, J. , Leal, J. , Maloutas, T. and Padovani, L. (2004). Housing and welfare in Southern Europe, Oxford: Blackwell.

Arundel, R. and Ronald, R. (2016). 'Parental co-residence, shared living and emerging adulthood in Europe: semi-dependent housing across welfare regime and housing system contexts', Journal of Youth Studies, 19(7), pp. 885-905.

Bliss, N. (2009). Bringing democracy home. West Bromwich: Commission for Cooperative and Mutual Housing.

Bogue, K. (2017). Precarious social housing: reforming policy, changing culture. An ethnographic case study on the impacts of the 'bedroom tax'. PhD thesis. University of Manchester.

Bone, J. and O'Reilly, K. (2010). 'No place called home: the causes and social consequences of the UK housing "bubble"', The British Journal of Sociology, 61(2), pp. 231-255.

Brenton, M. (2011). 'Cohousing: supportive local networks in old age', in Bunker, S. , Coates, C. , Field, M. and How, J. (eds) Cohousing in Britain: a Diggers and Dreamers review. London: Edge of Time Ltd., pp. 115-124.

Chatterton, P. (2015). Low impact living: a field guide to ecological, affordable community building. Abingdon: Routledge.

Clarke, A. and Heywood, A. (2016). 'Feasibility study of the prospect of developing a viable housing model for those entitled only to access the shared accommodation rate'. Report for Community Housing Cymru and the Welsh Local Government Association, Cambridge:

Cambridge Centre for Housing and Planning Research.

Cuming, E. (2016). Housing, class and gender in modern British writing 1880-2012. Cambridge: Cambridge University Press.

Davidoff, L. (1995). 'The separation of home and work? Landladies and lodgers in nineteenthand twentieth-century England', in Davidoff, L. (ed.) Worlds between: historical perspectives on gender \&class. Cambridge and Oxford: Polity Press, pp. 151-179.

Davies, K. and Heaphy, B. (2011). 'Interactions that matter: researching critical associations', Methodological Innovations Online, 6(3), pp. 5-16.

Department for Communities and Local Government (DCLG) (2013). Household interim projections, 2011-2021, England. London: DCLG Statistical Release.

Department for Communities and Local Government (DCLG) (2014). English Housing Survey: profile of English housing 2012, England. London: DCLG.

Department of Communities and Local Government (DCLG) (2016). English Housing Survey: headline report 2014-15. London: DCLG.

Department of Work and Pensions (DWP) (2015). Evaluation of removal of the Spare Room Subsidy: final report. London: DWP.

Dorling, D. (2014). All that is solid: how the great housing disaster defines our times, and what we can do about it. London: Allen Lane.

Druta, O. and Ronald, R. (2017). 'Young adults' pathways into homeownership and the negotiation of intra-family support: a home, the ideal gift', Sociology, 51(4), pp. 783-799.

Emmanuel, D. (2014). 'The Greek system of home ownership and the post-2008 crisis in Athens', Région et Développement, 39, pp. 167-182.

England, C. (2015). 'Property guardians; a solution to the UK's housing crisis?', Guardian, 24 March [online]. Available at: www.theguardian.com/sustainable-business/2015/mar/24/propertyguardians-housing-solution-opportunism

Flaquer, L. (2000). Family policy and welfare state in Southern Europe. Universitat Autônoma de Barcelona, Institut de Ciències Politieques i Socials, WP no. 185: 10.

Gibb, K. (2015). 'The multiple policy failures of the UK bedroom tax', International Journal of Housing Policy, 15(2), pp. 148-166.

Graber, H. and Wolfe, J. (2004). 'Family support centre village: a unique approach for lowincome single women and their children', Journal of Family Social Work, 8(1), pp. 61-73.

Green, S. and McCarthy, L. (2015). 'Is sharing the solution? Exploring the opportunities and challenges of privately rented shared accommodation for single people in housing need',

People, Place and Policy, 9(3), pp. 159-178. 
Greenstein, A. , Burman, E. , Lalambouka, A. and Sapin, K. (2016). 'Construction and deconstruction of "family" by the "bedroom tax"', British Politics, 11(4), pp. 508-525.

Griffith, M. (2011). Hoarding of housing: the intergenerational crisis in the housing market. London: The Intergenerational Foundation.

Hamlett, J. (2010). Material relations: domestic interiors and middle-class families in England, 1850-1910. Manchester: Manchester University Press.

Hansard (2010). HC Deb 20 October 2010, vol. 516, col. 958 [electronic version].

Hansard (2011). HC Deb 10 March 2011, vol. 496, col. 297WH [electronic version].

Harrison, M. and Reeve, K. (2002). 'Social welfare movements and collective action: lessons from two UK housing cases', Housing Studies, 17(5), pp. 755-771.

Heath, S. (2017). 'Young, free and single: alternative living arrangements', in Furlong, A. (ed.) Handbook of youth and young adulthood. 2nd edition. London: Routledge, pp. 199-205.

Heath, S. and Calvert, E. (2013). 'Gifts, loans and intergenerational support to young adults', Sociology, 47(6), pp. 1120-1135.

Heath, S. and Cleaver, E. (2003). Young, free and single: twenty somethings and household change. Basingstoke: Palgrave Macmillan.

Heath, S. and Kenyon, E. (2001). 'Single young professionals and shared household living', Journal of Youth Studies, 4(1), pp. 83-100.

Hoolachan, J. , McKee, K., Moore, T. and Soaita, A. (2017). " "Generation rent" and the ability to "settle down": economic and geographical variation in young people's housing transitions', Journal of Youth Studies, 20(1), pp. 63-78.

Howker, E. and Malik, S. (2010). Jilted generation: how Britain has bankrupted its youth. London: Icon Books.

Hunt, R. and Hutchinson, M. (2009). The essential guide to flatsharing: for sharers, lodgers and everyone renting out a room. Oxfordshire: How to Books Ltd.

Hutchinson, M. (2017). Trends in advertisements placed on SpareRoom website, Personal communication, 25 April 2017.

Jarvis, H. (2011). 'Saving space, sharing time: integrated infrastructures of daily life in cohousing', Environment and Planning A, 43(3), pp. 560-577.

Kearns, K. (1981). 'Urban squatter strategies: social adaptation to housing stress in London', Urban Life, 10(2), pp. 123-153.

Kemeny, J. (2005). '“The really big trade-off" between home ownership and welfare: Castles' evaluation of the 1980 thesis, and a reformulation 25 years on', Housing, Theory and Society, 22(2), pp. 59-75.

Kenyon, E. and Heath, S. (2001). 'Choosing This Life: Narratives of choice amongst house sharers', Housing Studies, 16(5), pp. 619-635.

Kenyon, L. (1999). 'A home from home: students' transitional experiences of housing', in Chapman, T. and Hockey, J. (eds) Ideal homes? Social change and domestic life. London: Routledge, pp. 84-95.

Lewis, J. , West, A. , Roberts, J. and Noden, P. (2016). 'The experience of co-residence: young adults returning to the parental home after graduation in England', Families, Relationships and Societies, 5(2), pp. 247-262.

LILAC Co-operative (2011). 'Affordable ownership in a low impact setting: LILAC', in Bunker, S. , Coates, C. , Field, M. and How, J. (eds) Cohousing in Britain: a Diggers and Dreamers review. London: Edge of Time Ltd., pp. 93-100.

Lloyd, M. , Peel, D. and Janssen- Jansen, L. (2015). 'Self-build in the UK and Netherlands: mainstreaming self-development to address housing shortages?', Urban, Planning and Transport Research, 3(1), pp. 10-31.

LV (2010). Press release: Boom in middle class households taking in lodgers. Available at: www.Iv.com/about-us/press/article/lodger-boom

Mandic, S. (2008). 'Home-leaving and its structural determinants in Western and Eastern Europe: an exploratory study', Housing Studies, 23(4), pp. 615-637.

Mandic, S. (2010). 'The changing role of housing assets in post-socialist countries', Journal of Housing and Built Environment, 25(2), pp. 213-226.

Mason, J. (2011). 'Facet methodology: the case for an inventive research orientation', Methodological Innovations Online, 6(3), pp. 75-92.

McCamant, K. and Durrett, C. (2011). Creating cohousing: building sustainable communities. Gabriola Island: New Society Publishers. 
McKee, K. (2012). 'Young people, home ownership and future welfare', Housing Studies, 27(6), pp. 853-862.

Moore, T. and McKee, K. (2012). 'Empowering local communities? An international review of community land trusts', Housing Studies, 27(2), pp. 280-290.

Mulder, K. , Costanza, R. and Erickson, J. (2006). 'The contribution of built, human, social and natural capital to quality of life in intentional and unintentional communities', Ecological Economics, 59(1), pp. 13-23.

Mulholland, T. (2016). British boarding houses in interwar women's literature: alternative domestic spaces. London: Routledge.

Munro, M. and Livingston, M. (2012). 'Student impacts on urban neighbourhoods: policy approaches, discourses and dilemmas', Urban Studies, 49(8), pp. 1679-1694.

Office for National Statistics (ONS) (2012). Young adults living with parents in the UK, 2011. London: ONS.

Office for National Statistics (ONS) (2014). Households and household composition in England and Wales: 2001-2011. London: ONS.

Office for National Statistics (ONS) (2015a). Statistical bulletin. Families and households: 2015. London: ONS.

Office for National Statistics (ONS) (2015b). Housing and home ownership in the UK. London: ONS. Available at: http://visual.ons.gov.uk/uk-perspectives-housing-and-home-ownership-inthe-uk/

Ortega-Alcazar, I. and Wilkinson, E. (2017). 'Just a room in a shared house: the impact of Housing Benefit cuts on single parents with non-resident children', Discover Society, 44.

Available at: http://discoversociety.org/2017/05/02/just-a-room-in-a-shared-house-the-impact-ofhousing-benefit-cuts-on-single-parents-with-non-resident-children/

Park, A. and Ziegler, F. (2016). 'A home for life? a critical perspective on housing choice for "downsizers" in the UK', Architecture, Media, Politics, Society, 9(2), pp. 1-21.

Parkinson, J. (2015). 'The return of the live-in lodger', BBC News, 8 December, [online].

Available at: www.bbc.co.uk/news/magazine-34982458

Pooley, C. and Turnbull, J. (1997). 'Leaving home: the experience of migration from the parental home in Britain since c. 1770', Journal of Family History, 22(4), pp. 390-424.

Radical Routes (2015). How to set up a housing co-op. 8th edition. Leeds: Footprint Workers Co-op.

Rigby, A. (1974). Alternative realities: a study of communes and their members. London:

Routledge and Kegan Paul.

Roberts, S. (2013). 'Youth studies, housing transitions and the 'missing middle': time for a rethink', Sociological Research Online, 18(3).

Roberts, J. , Noden, P. , West, A. and Lewis, J. (2016). 'Living with the parents: the purpose of young graduates' return to the parental home in England', Journal of Youth Studies, 19(3), pp. 319-337.

Rowlands, R. (2010). 'Housing scoping paper: co-operatives and mutual housing in the social rented sector', Briefing Paper 17, Birmingham: Third Sector Research Centre.

Rugg, J. and Quilgars, D. (2015). 'Young people and housing: a review of the present policy and practice landscape', Youth and Policy, 114, pp. 5-16. Available at: www.youthand policy.org/wp-content/uploads/2015/04/rugg-quilgars-young-people-and-housing1.pdf Rugg, J. and Rhodes, D. (2008). The private rented sector: its contribution and potential. York: Centre for Housing Policy.

Rugg, J. , Rhodes, D. and Wilcox, S. (2011). Unfair shares: a report on the impact of extending the shared accommodation rate of housing benefit. London: Crisis.

Sage, J. , Evandrou, M. and Falkingham, J. (2013). 'Onwards or homewards? Complex graduate migration pathways, well-being, and the "parental safety net"', Population, Space and Place, 19(6), pp. 738-755.

Sanders, B. and Texeira, L. (2012). No room available: study of the availability of shared accommodation. London: Crisis.

Saunders, P. (2016). What went wrong with home ownership in Britain and how to start putting it right. London: Civitas.

Sargisson, L. (2011). 'Cohousing evolution in Scandinavia and the USA', in Bunker, S. , Coates, C. , Field, M. and How, J. (eds) Cohousing in Britain: a Diggers and Dreamers review. London: Edge of Time Ltd., pp. 115-124. 
Sargisson, L. (2012). 'Second-wave cohousing: a modern utopia?', Utopian Studies, 23(1), pp. 28-56.

Sazama, G. (2003). 'Lessons from the history of affordable housing co-operatives in the United States', American Journal of Economics and Sociology, 59(4), pp. 573-608.

SharedLivesPlus (2016). Homeshare sector report, summer 2016. Liverpool: SharedLivesPlus. Shepperson, T. (2010). The quick guide to taking in a lodger. London: Lawpack Publishing Ltd. Shin Choi, J. (2004). 'Evaluation of community planning and life of senior cohousing projects in northern European countries', European Planning Studies, 12(8), pp. 1189-1216.

Steinfuhrer, A. and Haase, A. (2009). 'Flexible-inflexible: socio-demographic, spatial and temporal dimensions of flat sharing in Leipzig (Germany)', GeoJournal, 74(6), pp. 567-587. Stephens, M. and Stephenson, A. (2016). 'Housing policy in the austerity age and beyond', in Fenger, M. , Hudson, J. and Needham, C. (eds) Social Policy Review 28: Analysis and Debate in Social Policy, 28, Bristol: Policy Press, pp. 63-85.

Stone, J. , Berrington, A. and Falkingham, J. (2014). 'Gender, turning points, and boomerangs: Returning home in young adulthood in Great Britain', Demography, 51(1), pp. 257-276.

Walker, R. and Jeraj, S. (2016). The rent trap: how we fell into it and how we get out of it. London: Pluto Press.

Walton, J. (1978). The Blackpool landlady: a social history. Manchester: Manchester University Press.

Wann, D. (ed.) (2005). Reinventing community: stories from the walkways of cohousing. Golden, CO: Fulcrum Publishing.

Waters, S. (2014). The paying guests. London: Virago Press.

Wesolowicz, E. and Derham, R. (2017). Spare to share: setting up and supporting shared tenancies in social housing. London: Crisis.

Willetts, D. (2010). The pinch: how the baby boomers took their children's future - and how they can give it back. London: Atlantic Books.

Williams, J. (2005a). 'Sun, surf and sustainable housing: cohousing, the Californian experience', International Planning Studies, 10(2), pp. 145-177.

Williams, J. (2005b). 'Designing neighbourhoods for social interaction: the case of cohousing', Journal of Urban Design, 10(2), pp. 195-227.

\section{Shared living and domestic intimacy}

Abrams, P. , McCulloch, A. , Abrams, S. and Gore, P. (1976). Communes, sociology and society. Cambridge: Cambridge University Press.

Allan, G. (1989). 'Insiders and outsiders: boundaries around the home', in Allan, G. and Crow, G. (eds) Home and family: creating the domestic sphere. Basingstoke: Macmillan, pp. 141-148. Atkinson, R. and Jacobs, K. (2016). House, home and society, Basingstoke: Palgrave Macmillan.

Belk, R. (2010). 'Sharing', Journal of Consumer Research, 36(5), pp. 715-734.

Blackwood, E. (2005). 'Wedding bell blues: marriage, missing men, and matrifocal follies', American Ethnologist, 32(1), pp. 3-19.

Botsman, R. and Rogers, R. (2011). What's yours is mine: how collaborative consumption is changing the way we live. London: HarperCollins.

Burikova, Z. and Miller, D. (2010). Au pair. Cambridge: Polity Press.

Cuming, E. (2016). Housing, class and gender in modern British writing 1880-2012. New York: Cambridge University Press.

Davidoff, L. (1995). 'The separation of home and work? Landladies and lodgers in nineteenthand twentieth-century England, in Davidoff, L. (ed.) Worlds between: historical perspectives on gender \&class. Cambridge and Oxford: Polity Press, pp. 151-179.

Davidoff, L. and Hall, C. (1987). Family fortunes: men and women of the English middle class 1780-1850. Chicago: University of Chicago Press.

Davies, K. and Heaphy, B. (2011). 'Interactions that matter: researching critical associations', Methodological Innovations Online, 6(3), pp. 5-16. 
Devine, F. and Heath, S. (1999). Sociological research methods in context. Basingstoke: Macmillan.

Dupuis, A. and Thorns, D. (1998). 'Home, home ownership and the search for ontological security', Sociological Review, 46(1), pp. 24-47.

Easthope, H. (2014). 'Making a rental property home', Housing Studies, 29(5), pp. 579-596. Easthope, H. , Liu, E. , Judd, B. and Burnley, I. (2015). 'Feeling at home in a multigenerational household: the importance of control', Housing, Theory and Society, 32(2), pp. 151-170.

Fromm, D. (1991). Collaborative communities: cohousing, central living and other forms of new housing with shared facilities. New York: Van Nostrand Reinhold.

Giddens, A. (1990). The consequences of modernity. California: Stanford University Press. Gouldner, A. (1973). For sociology: renewal and critique in sociology today. London: Allen Lane. Green, G. , Barratt, C. and Wiltshire, M. (2016). 'Control and care: landlords and the governance of vulnerable tenants in houses in multiple occupation', Housing Studies, 31(3), pp. 269-286.

Green, S. and McCarthy, L. (2015). 'Is sharing the solution? Exploring the opportunities and challenges of privately rented shared accommodation for single people in housing need', People, Place and Policy, 9(3), pp. 159-178.

Gregory, C.A. (1982). Gifts and commodities. London: Academic Press.

Griffith, M. (2011). Hoarding of housing: the intergenerational crisis in the housing market. London: The Intergenerational Foundation.

Gubrium, J. and Holstein, J. (1987). 'The private image: experiential location and method in family studies', Journal of Marriage and Family, 49(4), pp. 773-786.

Hayden, D. (1981). The grand domestic revolution. Cambridge, MA: MIT Press.

Heath, S. (2004). 'Shared households, quasi-communes and neo-tribes', Current Sociology, 52(2), pp. 161-179.

Heynen, H. (2005). 'Modernity and domesticity: tensions and contradictions', in Heynen, H. and Baydar, G. (eds) Negotiating domesticity: spatial productions of gender in modern architecture. London: Routledge, pp. 101-113.

Hiscock, R. , Kearns, A. , Maclntyre, S. and Ellaway, A. (2001). 'Ontological security and psycho-social benefits from the home: qualitative evidence on issues of tenure', Housing, Theory and Society, 18(1-2), pp. 50-66.

Ingold, T. (1986). The appropriation of nature: essays on human ecology and social relations. Manchester: Manchester University Press.

John, N. (2013). 'The social logics of sharing', The Communication Review, 16(3), pp. 113-131. Johnston, L. and Valentine, G. (1995). 'Wherever I lay my girlfriend, that's my home: the performance and surveillance of lesbian identities in domestic environments', in Bell, D. and Valentine, G. (eds) Mapping desire: geographies of sexualities. London: Routledge, pp. 99-113. Jones, G. (2000). 'Experimenting with households and inventing "home"', International Social Science Journal, 52(2), pp. 183-194.

King, P. (2004). Private dwelling: contemplating the use of housing. London: Routledge.

Luzia, K. (2011). 'Growing home', Home Cultures, 8(3), pp. 297-316.

Maffesoli, M. (1996). The time of the tribes: the decline of individualism in mass society. London: SAGE.

Mauss, M. (1967 [1925]). The gift: forms and functions of exchange in archaic societies, Cunnison, I. (trans.). New York: Norton.

Morgan, D. (1996). Family connections: an introduction to family studies. Oxford and Cambridge: Polity Press.

Morgan, D. (2009). Acquaintances: the space between intimates and strangers. Maidenhead: Open University Press/McGraw-Hill.

Munro, M. and Madigan, R. (1993). 'Privacy in the private sphere', Housing Studies, 8(1), pp. 29-45.

Ortega-Alcazar, I. and Wilkinson, E. (2017). 'Just a room in a shared house: the impact of Housing Benefit cuts on single parents with non-resident children', Discover Society, Issue 44. Available at: http://discoversociety.org/2017/05/02/just-a-room-in-a-shared-house-the-impact-ofhousing-benefit-cuts-on-single-parents-with-non-resident-children/

Pilkey, B. , Scicluna, R. and Gorman-Murray, A. (2015). 'Alternative domesticities', Home Cultures, 12(2), pp. 127-138. 
Rigby, A. (1974). Alternative realities: a study of communes and their members. London: Routledge and Kegan Paul.

Rybczynski, W. (1988). Home: a short history of the idea. London: Heinemann.

Rugg, J. and Rhodes, D. (2008). The private rented sector: its contribution and potential. York: Centre for Housing Policy.

Rugg, J. , Rhodes, D. and Wilcox, S. (2011). Unfair shares: a report on the impact of extending the shared accommodation rate of housing benefit. London: Crisis.

Sargent, L.T. (1994). 'The three faces of utopianism revisited', Utopian Studies, 5(1), pp. 1-37. Sargisson, L. (2012). 'Second-wave cohousing: a modern utopia?', Utopian Studies, 23(1), pp. 28-56.

Saunders, P. (1990). A nation of home owners. London: Unwin Hyman.

Saunders, S. and Williams, P. (1988). 'The constitution of the home: towards a research agenda', Housing Studies, 3(2), pp. 81-93.

Scicluna, R. (2015). 'Thinking through domestic pluralities', Home Cultures, 12(2), pp. 169-191.

Simmel, G. (1950). 'Faithfulness and gratitude', in Wolff, K. (eds) The sociology of Georg Simmel. New York: The Free Press, pp. 379-395.

Smart, C. , Davies, K. , Heaphy, B. and Mason, J. (2012). 'Difficult friendships and ontological insecurity', The Sociological Review, 60(1), pp. 91-109.

Smith, M. , Albanese, F. and Truder, J. (2014). A roof over my head: the final report of the Sustain Project, a longitudinal study of housing outcomes and wellbeing in private rented accommodation. London: Shelter.

Spencer-Wood, S. (1999). 'The world their household: changing meanings of the domestic sphere in the nineteenth century', in Allison, P. (ed.) The archaeology of household activities: dwelling in the past. London: Routledge, pp. 162-189.

Stephany, A. (2015). The business of sharing: making it in the new sharing economy. London: Palgrave Macmillan.

Strathern, M. (1995). The relation: issues in complexity and scale. Cambridge: Prickly Pear Press.

Taylor, B. (1983). Eve and the new Jerusalem: socialism and feminism in the nineteenth century. London: Virago Press.

Walker, R. and Jeraj, S. (2016). The rent trap: how we fell into it and how we get out of it. London: Pluto Press.

Ward, K. (2015). 'Geographies of exclusion: seaside towns and houses in multiple occupancy', Journal of Rural Studies, 37(1), pp. 96-107.

Williams, J. (2005). 'Designing neighbourhoods for social interaction: the case of cohousing', Journal of Urban Design, 10(2), pp. 195-227.

Wolff, K. (1950). The sociology of Georg Simmel. New York: The Free Press.

Yates, L. (2016). 'Sharing, households and sustainable consumption', Journal of Consumer Culture [preprint]. Available at: 10.1177/1469540516668229 html

\section{Pathways into sharing}

Abrams, P. , McCulloch, A., Abrams, S. and Gore, P. (1976). Communes, sociology and society. Cambridge: Cambridge University Press.

Blackwood, E. (2005). 'Wedding bell blues: marriage, missing men, and matrifocal follies', American Ethnologist, 32(1), pp. 3-19.

Brenton, M. (2011). 'Cohousing: supportive local networks in old age', in Bunker, S. , Coates, C.

, Field, M. and How, J. (eds) Cohousing in Britain: a Diggers and Dreamers review. London:

Edge of Time Ltd., pp. 115-124.

Carsten, J. (2000). Cultures of relatedness: new approaches to the study of kinship. Cambridge: Cambridge University Press.

Collier, J. , Rosaldo, M. and Yanagisako, S. (1997). 'Is there a family? New anthropological views', in Lancaster, R. and di Leonardo, M. (eds) The gender/sexuality reader, London: Routledge, pp. 71-81. 
Durrett, C. (2009). The senior cohousing handbook: a community approach to independent living. Gabriola Island: New Society Publishers.

Eurostat (2015). Marriage and Divorce Statistics [online]. Available at:

http://ec.europa.eu/eurostat/statistics-explained/index.php/Marriage_and_divorce_statistics Grandits, H. (ed.) (2010). Family, kinship and the state in contemporary Europe, Volume 1: The Century of Welfare. Chicago: University Chicago Press.

Guyer, J. (2015). 'Housing as "capital”', Hau: Journal of Ethnographic Theory, 5(1), pp. 495-500.

Hayden, D. (1981). The grand domestic revolution: a history of feminist designs for American homes, neighbourhoods and cities, MIT Press.

Heath, S. (2004). 'Shared households, quasi-communes and neo-tribes', Current Sociology, 52(2), pp. 161-179.

Heath, S. (2017). 'Young, free and single: alternative living arrangements', in Furlong, A. (ed.) Handbook ofyouth and young adulthood. 2nd edition. London: Routledge, pp. 199-205.

Marshall, L. (2017). 'Castle and cell: exploring intersections between sexuality and gender in the domestic lives of men with trans identities and histories', in Pilkey, B. , Scicluna R.M., Campkin, B. and Penner, B. (eds) Sexuality and gender at home: experience, politics, transgression. London: Bloomsbury, pp. 183-201.

Jarvis, H. and Bonnett, A. (2013). 'Progressive nostalgia in novel living arrangements: a counterpoint to neo-traditional new urbanism', Urban Studies, 50(11), pp. 2349-2370.

Kearns, K. (1981). 'Urban squatter strategies: social adaptation to housing stress in London', Urban Life, 10(2), pp. 123-153.

McCamant, K. and Durrett, C. (2011). Creating cohousing: building sustainable communities. Gabriola Island: New Society Publishers.

McKee, K. (2012). 'Young people, home ownership and future welfare', Housing Studies, 27(6), pp. 853-862.

Messana, P. (2011) Soviet communal living: an oral history of the Kommunalka. Basingstoke: Palgrave Macmillan.

Nash, J. and Hopkins, N.S. (1976). 'Anthropological approaches to the study of cooperatives, collectives, and self-management', in Nash, J. , Dandler, J. and Hopkins, N.S. (eds) Popular participation in social change: cooperatives, collectives and nationalized industry. The Hague and Paris: Mouton Publishers, pp. 3-35.

Oerton, S. (1997). " "Queering housewives?": some problems in theorising the division of domestic labour in lesbian and gay households', Women's Studies International Forum, 20(3), pp. $421-430$.

Pearson, L. (1988). The architectural and social history of cooperative living, London:

Macmillan.

Pilkey, B. , Scicluna R.M. , Campkin, B. and Penner, B. (2017). Sexuality and gender at home: experience, politics, transgression. London: Bloomsbury.

Pilkey, B. , Scicluna, R. and Gorman-Murray, A. (2015). 'Alternative domesticities: a crossdisciplinary approach to home and sexuality", Home Cultures, 2(2), pp. 1-15.

Roberts, S. (2013). 'Youth studies, housing transitions and the 'missing middle': time for a rethink', Sociological Research Online, 18(3).

Sargisson, L. (2010). 'Co-Housing: A Utopian Property Alternative?', Centre for the Study of Social and Global Justice [working paper] 014.

Sargisson, L. (2011). 'Cohousing evolution in Scandinavia and the USA', in Bunker, S. , Coates, C. , Field, M. and How, J. (eds) Cohousing in Britain: a Diggers and Dreamers review. London: Edge of Time Ltd., pp. 115-124.

Scicluna, R.M. (2015). 'Thinking through domestic pluralities: kitchen stories from the lives of older lesbians in London', Home Cultures, 12(2), pp. 169-191.

Scicluna, R.M. (2017). Home and sexuality: the 'other' side of the kitchen. Basingstoke:

Palgrave Macmillan.

Shin Choi, J. (2004). 'Evaluation of community planning and life of senior cohousing projects in northern European countries', European Planning Studies, 12(8), pp. 1189-1216.

Simpson, B. (1998). Changing families: an ethnographic approach to divorce and separation. Oxford and New York: Berg.

Wilkinson, E. (2014). 'Single people's geographies of home: intimacy and friendship beyond the family', Environment and Planning A, 46(10), pp. 2452-2468. 


\section{The economic and material organisation of shared living}

Abrams, P. , McCulloch, A. , Abrams, S. and Gore, P. (1976). Communes, sociology and society. Cambridge: Cambridge University Press.

Belk, R. (2010). 'Sharing', Journal ofConsumer Research, 36(5), pp. 715-734.

Birchall, J. (1999). 'What makes people participate in cooperatives? Towards a theoretical model', Journal of Rural Cooperation, 27(1), pp. 3-15.

Burikova, Z. and Miller, D. (2010). Au pair. Cambridge: Polity Press.

Carlsson, M. and Eriksson, S. (2015). 'Ethnic discrimination in the London market for shared housing', Journal of Ethnic and Migration Studies, 41(8), pp. 1276-1301.

Chatterton, P. (2015). Low impact living: a field guide to ecological, affordable community building. Abingdon; Routledge.

Clarke, A. and Heywood, A. (2016). 'Feasibility study of the prospect of developing a viable housing model for those entitled only to access the shared accommodation rate'. Report for community housing Cymru and the Welsh Local Government Association. Cambridge:

Cambridge Centre for Housing and Planning Research.

Coates, C. (2011). 'Key development stages: Forgebank', in Bunker, S. , Coates, S. , Field, M. and How, J. (eds) Cohousing in Britain: a Diggers and Dreamers review. London: Edge of Time Ltd., pp. 11-22.

King, P. (2004). Private dwelling: contemplating the use of housing. London: Routledge. Lashley, C. , Lynch, P. and Morrison, A. (eds) (2007). Hospitality: a social lens. London: Routledge.

McCamant, K. and Durrett, C. (2011). Creating cohousing: building sustainable communities. Gabriola Island: New Society Publishers.

Meltzer, G. (2011). 'Close relationships: learning from the cohousing model', in Bunker, S. , Coates, S. , Field, M. and How, J. (eds) Cohousing in Britain: a Diggers and Dreamers review. London: Edge of Time Ltd., pp. 43-58.

Radical Routes (2015). How to set up a housing co-op. 8th edition. Leeds: Footprint Workers Co-op.

Seymour, J. (2015). 'More than putting on a performance in commercial homes: merging family practices and critical hospitality studies', Annals of Leisure Research, 8(3), pp. 414-530.

Shepperson, T. (2010). The quick guide to taking in a lodger. London: Lawpack Publishing Ltd.

\section{The spatial organisation of shared living}

Abu-Ghazzeh, T.M. (1999). 'Housing layout, social interaction, and the place of contact in AbuNuseir, Jordan', Journal of Environmental Psychology, 19(1), pp. 41-73.

Allan, G. and Crow, G. (eds) (1989). Home and family: creating the domestic sphere.

Basingstoke: Macmillan.

Alexander, C. , Silverstein, M. and Ishikawa, S. (1977). A pattern language: towns, buildings, construction. Oxford: Oxford University Press.

Blake, R.R. , Rhead, C.C. , Wedge, B. and Mouton, J.S. (1956). 'Housing architecture and social interaction', Sociometry, 19(2), pp. 133-139.

Bowlby, S. , Gregory, S. and McKie, L. (1997). '“Doing home”: patriarchy, caring and space', Women's Studies International Forum, 20(3), pp. 343-350.

Bunker, S. , Coates, C. , Field, M. and How, J. (eds) (2011). Cohousing in Britain: a Diggers and Dreamers review. London: Edge of Time Ltd.

Devlin, A.S. , Donovan, S. , Nicolov, A. , Nold, O.I. and Zandan, G. (2008). 'Residence hall architecture and sense of community: everything old is new again', Environment and Behaviour, 40(4), pp. 487-521.

Edwards, R. , Hadfield, L. , Lucey, H. and Mauthner, M. (2006). Sibling identity and relationships: sisters and brothers. London: Routledge.

Franck, K. and Anrentzen, S. (1989). New households, new housing. New York: Van Nostrand Reinhold.

Fromm, D. (1991). Collaborative communities: cohousing, central living and other forms of new housing with shared facilities. New York: Van Nostrand Reinhold. 
Gurney, C. (2000). 'Transgressing private-public boundaries in the home: a sociological analysis of the coital noise taboo', Venereology, 13(1), pp. 39-46.

Jarvis, H. (2011). 'Saving space, sharing time: integrated infrastructures of daily life in cohousing', Environment and Planning A, 43(3), pp. 560-577.

Madigan, R. and Munro, M. (1999). "The more we are together": domestic space, gender and privacy', in Chapman, T. and Hockey, J. (eds) Ideal home? Social change and domestic life. London and New York: Routledge, pp. 61-72.

McCamant, K. and Durrett, C. with Hertzman, E. (1994). Cohousing: a contemporary approach to housing ourselves. Berkeley, CA: Ten Speed Press.

Morgan, D. (1996). Family connections. Cambridge: Polity Press.

Nippert-Eng, C. (2010). Islands of privacy. Chicago, IL and London: University of Chicago

Press.

Palm Linden, K. (1992). Community and privacy in the Swedish collective house. Lund: University of Lund. Available at: www.kollektivhus.nu/uppsatser.html

Rechavi, T.B. (2009). 'A room for living: private and public aspects in the experiences of the living room', Journal of Environmental Psychology, 29(1), pp. 133-143.

Rosenblatt, T. , Cheshire, L. and Lawrence, G. (2009). 'Social interaction and sense of community in a master planned community', Housing, Theory and Society, 26(2), pp. 122-142. Ruiu, M.L. (2015). 'The social capital of cohousing communities', Sociology, 50(2), pp. 1-16. Saunders, P. and Williams, P. (1988). 'The constitution of the home: towards a research agenda', Housing Studies, 3(2), pp. 81-93.

Scicluna, R.M. (2017). Home and sexuality: the 'other' side of the kitchen. UK and USA: Palgrave Macmillan.

Seymour, J. (2011). 'on not going home at the end of the day: spatialized discourses of family life in single location home/workplaces', in Holt, L. (ed.) Geographies of children, youth and families: an international perspective. London: Routledge, pp. 108-120.

Stevenson, F. , Baker, H. and Fewson, K. (2013). 'Cohousing case studies in the UK: Is sharing facilities really resourceful? Presented at PLEA2013, Sustainable Architecture for a Renewable Future, Munich, Germany, 10-12 September.

Williams, J. (2005). 'Designing neighbourhoods for social interaction: the case of cohousing', Journal of Urban Design, 10(2), pp. 195-227.

\section{Time matters in shared living}

Allan, G. and Crow, G. (eds) (1989). Home and family: creating the domestic sphere. Basingstoke: Macmillan.

Altman, I. (1975). The environment and social behavior: privacy, personal space, territory, crowding. Monterey, CA: Brooks/Cole Publishing Company.

Arundel, R. and Ronald, R. (2016). 'Parental co-residence, shared living and emerging adulthood in Europe: semi-dependent housing across welfare regime and housing system contexts', Journal of Youth Studies, 19(7), pp. 885-905.

Bennett, C.J. and Grant, R. (eds) (1999). Visions ofprivacy: policy choices for the digital age. Toronto: University of Toronto Press.

Birchall, J. (1999). 'What makes people participate in cooperatives? Towards a theoretical model', Journal of Rural Cooperation, 27(1), pp. 3-15.

Blank, J. (2001). 'Common meals in cohousing communities' [online]. Available at: www.cohousing.org/meals-2001

Bone, J. and O'Reilly, K. (2010). 'No place called home: the causes and social consequences of the UK housing "bubble"', The British Journal of Sociology, 61(2), pp. 231-255.

Chapman, T. and Hockey, J. (1999). 'The ideal home as it is imagined and as it is lived', in Chapman, T. and Hockey, J. (eds) Ideal home? Social change and domestic life. London and New York: Routledge, pp. 1-13.

Crow, G. (1989). 'The post-war development of the modem domestic ideal', in Allan, G. and Crow, G. (eds) Home and family: creating the domestic sphere. Basingstoke: Macmillan, pp. 14-32. 
Daly, K.J. (1996). Families and time: keeping pace in a hurried culture. Thousand Oaks, CA and London: SAGE.

Davey, A.J. and Paolucci, B. (1980). 'Family interaction: a study of shared time and activities', Family Relations, 29(1), pp. 43-49.

Dupuis, A. and Thorns, D.C. (1998). 'Home, home ownership and the search for ontological security', The Sociological Review, 46(1), pp. 24-47.

Easthope, H. , Liu, E. , Judd, B. and Burnley, I. (2015). 'Feeling at home in a multigenerational household: the importance of control', Housing, Theory and Society, 32(2), pp. 151-170.

Fromm, D. (1991). Collaborative communities: cohousing, central living and other forms of new housing with shared facilities. New York: Van Nostrand Reinhold.

Giddens, A. (1990). The consequences of modernity. Cambridge: Polity Press.

Glyptis, S.A. and Chambers, D.A. (1982). 'No place like home', Leisure Studies, 1(1), pp. 247-262.

Goffman, E. (1969). The presentation of self in everyday life. London: Penguin Books. Goldstack, L. (1999). 'A haven in a heartless world? Women and domestic violence', in Chapman, T. and Hockey, J. (eds) Ideal home? Social change and domestic life. London and New York: Routledge, pp. 121-132.

Gurney, C. (2000). 'Transgressing private-public boundaries in the home: a sociological analysis of the coital noise taboo', Venereology, 13(1), pp. 39-46.

Guyer, J. (2015). 'Housing as "capital"', Hau: Journal of Ethnographic Theory, 5(1), pp. 495-500.

Heath, S. (2017). 'Young, free and single: alternative living arrangements', in Furlong, A. (ed.) Handbook of youth and young adulthood. 2nd edition. London: Routledge, pp. 199-205.

Heath, S. and Kenyon, E. (2001). 'Single young professionals and shared household living', Journal of Youth Studies, 4(1), pp. 83-100.

Hutchinson, S.L. , Afifi, T. and Krause, S. (2007). 'The family that plays together fares better', Journal of Divorce \&Remarriage, 46(3-4), pp. 21-48.

Jamieson, L. (2011). 'Intimacy as a concept: explaining social change in the context of globalisation or another form of ethnocentricism?', Sociological Research Online, 16(4), p. 15. Available at: www.socresonline.org.uk/16/4715.html

Jarvis, H. (2011). 'Saving space, sharing time: integrated infrastructures of daily life in cohousing', Environment and Planning A, 43(3), pp. 560-577.

Jarvis, H. (2015). 'Towards a deeper understanding of the social architecture of cohousing: evidence from the UK, USA and Australia', Urban Research \&Practice, 8(1), pp. 93-105. Jarvis, H. and Bonnett, A. (2013). 'Progressive nostalgia in novel living arrangements: a counterpoint to neo-traditional new urbanism', Urban Studies, 50(11), pp. 2349-2370.

Korpela, S. (2012). 'Casa Malta: a case study of a contemporary co-housing project in Helsinki', Built Environment, 38(3), pp. 336-344.

Livingstone, S. (2007). 'From family television to bedroom culture: young people's media at home', in Devereux, E. (ed.) Media studies: key issues and debates. London: SAGE, pp. 302-321.

Lyon, D. (2001). Surveillance society: monitoring everyday life. Buckingham and Philadelphia, PA: Open University Press.

Magi, T.J. (2011). 'Fourteen reasons privacy matters: a multidisciplinary review of scholarly literature', Library Quarterly, 81(2), pp. 187-209.

McCamant, K. and Durrett, C. with Hertzman, E. (1994). Cohousing: a contemporary approach to housing ourselves. Berkeley, CA: Ten Speed Press.

McKie, L. and Cunningham-Burley, S. (eds) (2005). Families in society: boundaries and relationships. Bristol: The Policy Press.

Meltzer, G. (2011). 'Close relationships: learning from the cohousing model', in Bunker, S. , Coates, S. , Field, M. and How, J. (eds) Cohousing in Britain: a Diggers and Dreamers review. London: Edge of Time Ltd., pp. 43-58.

Merton, R. (1996). On social structure and science. Chicago: University of Chicago Press. Morgan, D. (1996). Family connections. Cambridge: Polity Press.

Morgan, D. (2009). Acquaintances: the space between intimates and strangers. London: Open University Press.

Morgan, D. (2011). Rethinking family practices. Basingstoke: Palgrave Macmillan. 
Munro, M. and Madigan, R. (1993). 'Privacy in the private sphere', Housing Studies, 8(1), pp. 29-45.

Munro, M. and Madigan, R. (1999). 'Negotiating space in the family home', in Cieraad, I. (ed.) At home: an anthropology of domestic space. Syracuse, NY: Syracuse University Press, pp. 107-117.

Newell, P.B. (1995). 'Perspectives on privacy', Journal of Environmental Psychology, 15(2), pp. 87-104.

Nippert-Eng, C. (2010). Islands of privacy. Chicago, IL and London: University of Chicago Press.

Parke, R.D. (1978). 'Children's home environments: social and cognitive effects', in Altman, I. and Wohlwill, J.F. (eds) Children and the environment. New York: Plenum, pp. 33-81.

Rechavi, T.B. (2009). 'A room for living: private and public aspects in the experience of the living room', Journal of Environmental Psychology, 29(1), pp. 133-143.

Rosen, J. (2000). The unwanted gaze: the destruction of privacy in America. New York: Vintage.

Rosenblatt, T. , Cheshire, L. and Lawrence, G. (2009). 'Social interaction and sense of community in a master planned community, Housing, Theory and Society, 26(2), pp. 122-142.

Rosselin, C. (1999). 'The ins and outs of the hall: a Parisian example', in Cieraad, I. (ed.) At home: An anthropology of domestic space. Syracuse, NY: Syracuse University Press, pp. 53-59.

Ruiu, M.L. (2015). 'The social capital of cohousing communities', Sociology, 50(2), pp. 1-16. Sack, R. (1992). Place, modernity, and the consumer's world: a relational framework for geographical analysis. Baltimore: The Johns Hopkins University Press.

Steinfuhrer, A. and Haase, A. (2009). 'Flexible-inflexible: socio-demographic, spatial and temporal dimensions of flat sharing in Leipzig (Germany)', GeoJournal, 74(6), pp. 567-587.

Tummers, L. (2015). 'The re-emergence of self-managed co-housing in Europe: a critical review of co-housing research', Urban Studies, 53(10), 2023-2040.

Waitt, G. and Gorman-Murray, A. (2007). 'Homemaking and mature age gay men 'down under': paradox, intimacy, subjectivities, spatialities and scale', Gender, Place \&Culture, 14(5), pp. 569-584.

Waters, S. (2014). The paying guests. London: Virago Press.

Young, I.M. (1997). 'House and home: Feminist variations on a theme', in Intersecting voices: dilemmas of gender, political philosophy and policy. Princeton, NJ: Princeton University Press, pp. 134-164.

Zerubavel, E. (1979). 'Private time and public time: the temporal structure of social accessibility and professional commitments', Social Forces, 58(1), pp. 38-58.

\section{Shared housing, shared lives?}

Allan, G. (1989). 'Insiders and outsiders: boundaries around the home', in Allan, G. and Crow, G. (eds) Home and family: creating the domestic sphere. Basingstoke: Macmillan, pp. 141-148. Beck, U. and Beck-Gernsheim, E. (1995). The normal chaos of love. Cambridge: Polity Press. Burikova, Z. and Miller, D. (2010). Aupair. Cambridge: Polity Press.

Davies, K. and Heaphy, B. (2011). 'Interactions that matter: researching critical associations', Methodological Innovations Online, 6(3), pp. 5-16.

Giddens, A. (1993). The transformation of intimacy: sexuality, love and eroticism in modern societies. Cambridge: Polity Press.

Gorman-Murray, A. (2007). 'Reconfiguring domestic values: meanings of home for gay men and lesbians', Housing, Theory and Society, 24(3), pp. 229-246.

Green, S. and McCarthy, L. (2015). 'Is sharing the solution? Exploring the opportunities and challenges of privately rented shared accommodation for single people in housing need', People, Place and Policy, 9(3), pp. 159-178.

Gurney, C. (2000). 'Transgressing private-public boundaries in the home: a sociological analysis of the coital noise taboo', Venereology, 13(1), pp. 39-46. 
Jamieson, L. and Simpson, R. (2013). Living alone: globalization, identity and belonging. Basingstoke: Palgrave Macmillan.

Jarvis, H. (2011). 'Saving space, sharing time: integrated infrastructures of daily life in cohousing', Environment and Planning A, 43(3), pp. 560-577.

King, P. (2004). Private dwelling: contemplating the use of housing. London: Routledge. Morgan, D. (1996). Family connections: an introduction to family studies. Oxford and Cambridge: Polity Press.

Nippert-Eng, C. (2010). Islands of privacy. Chicago, IL and London: University of Chicago Press.

Ortega-Alcazar, I. and Wilkinson, E. (2017). 'Just a room in a shared house: the impact of Housing Benefit cuts on single parents with non-resident children', Discover Society, Issue 44. Available at: http://discoversociety.org/2017/05/02/just-a-room-in-a-shared-house-the-impact-ofhousing-benefit-cuts-on-single-parents-with-non-resident-children/

Pilkey, B. , Scicluna, R. and Gorman-Murray, A. (2015). 'Alternative domesticities: a crossdisciplinary approach to home and sexuality", Home Cultures, 2(2), pp. 1-15.

Rosenblatt, T. , Cheshire, L. and Lawrence, G. (2009). 'Social interaction and sense of community in a master planned community', Housing, Theory and Society, 26(2), pp. 122-142. Sanders, B. and Texeira, L. (2012). No room available: study of the availability of shared accommodation. London: Crisis.

Smart, C. (2007). Personal life. Cambridge: Polity Press.

Walker, R. and Jeraj, S. (2016). The rent trap: how we fell into it and how we get out of it. London: Pluto Press.

Waters, S. (2014). The paying guests. London: Virago Press.

Wesolowicz, E. and Derham, R. (2017). Spare to share: setting up and supporting shared tenancies in social housing. London: Crisis.

Williams, J. (2005). 'Sun, surf and sustainable housing: cohousing, the Californian experience', International Planning Studies, 10(2), 145-177. 